Zlatko Lagumdžija, $\mathrm{PhD}^{1}$

Amra Kapo, $\mathrm{PhD}^{2}$

Lejla Turulja, $\mathrm{PhD}^{3}$

\title{
FROM COMPETITIVENESS TO SUSTAINABILITY: IS THE INNOVATIVENESS THE ANSWER?
}

\begin{abstract}
We live in a rapidly changing global society, where no one can predict the outcome of the economic, social, and political structures of the world. Changes in science, technology, and economics are particularly noticeable and are closely linked to human life. These changes create new opportunities but also challenges in new areas of everyday activity in order to achieve sustainable development. For countries to compete with each other, they must be creative and innovative in all fields to cope with domestic, national, and global issues. Current economic competitiveness is based on the capabilities of a country and their respective companies to be and stay innovative. This is the main reason why many governments place innovativeness at the center of their growth strategies so that they can foster economic progress and global competitiveness in general. The recognition and need for identification of innovation as a driver of change are evident on a company level as well. This study will use secondary data collected this year from the World Economic Forum to identify critical challenges and opportunities for $B \& H$ competitiveness. Also, the results of this research identified enabling environment and markets impact on the innovation ecosystem. Practical contribution relates to concrete implications and recommendations that can be used for the improvement of Bosnia and Herzegovina innovativeness.
\end{abstract}

Keywords: innovativeness, innovation policy, innovation ecosystem, competitiveness, sustainable development

JEL: $O 30$

1 School of Economics and Business, University of Sarajevo; zlatko.lagumzija@efsa.unsa.ba

2 School of Economics and Business, University of Sarajevo; amra.kapo@efsa.unsa.ba

3 School of Economics and Business, University of Sarajevo; lejla.turulja@efsa.unsa.ba 


\section{INTRODUCTION}

The world has changed significantly in recent decades with the development of information technology, increased mobility and access to information (Fonseca \& Lima, 2015), which have significantly contributed to increasing competitiveness (Kowal \& Paliwoda-Pękosz, 2017). From economies that were based on agriculture and then on production, economies today are based on information and knowledge (Şener \& Sarıdoğan, 2011). Competitiveness in a globalized world is considered successful when there is a balance between the economic requirement imposed by global markets and the social requirement of a nation formed by history, tradition, and value systems (Ciocanel \& Pavelescu, 2015). In today's world, technology is evolving rapidly, and competition is much more significant because it is global. On the other hand, consumer needs and expectations are continually increasing and changing, while product lifecycles are shortening. Firms should adapt to market structure and respond with innovative outputs in order to survive, provide a competitive advantage, make this advantage sustainable, maintain and increase their market share (Ince et al., 2016).

It is almost unanimously accepted that the path to economic competitiveness is mostly adequate through innovation. In other words, competitiveness is an economic growth factor that drives innovation (Kowal \& Paliwoda-Pękosz, 2017). Innovation enables rapid adaptation to the pace of technological change in order to increase competitiveness. Also, Porter (1990) argued that it is not the nations that are powerful, but the companies that operate in their territories. This is the main reason why many governments place innovation at the heart of their growth strategies to drive economic progress and global competitiveness in general (Şener \& Sarıdoğan, 2011). The importance of creating, analyzing, and sharing information leads us to the innovative survival skills that companies in today's global market need to achieve. Ince et al. (2016) suggest that innovativeness is vital for firms. The use of technology is mandatory, but making technology and innovation part of an economy's DNA is challenging in itself (Schwab, 2019) but necessary for companies to achieve competitive advantage through acts of innovation and to secure long-term success and to achieve sustainability. The basis for long-term economic growth in all economic models is technological change and innovation (Şener \& Sarıdoğan, 2011). In this regard, this paper aims to analyze the predictors and determinants of competitiveness of the innovation ecosystems worldwide. Specifically, this paper reveals critical innovation indicators in 141 countries around the world using the Global Competitiveness Index (GCI). The paper tests the multiple regression model and the impact of enabling environment, human capital, and market on innovation ecosystem in order to identify the most significant indicators of innovation ecosystem competitiveness. This provides both theoretical implications by defining the regression model of the 
innovation ecosystem of an economy and practical implications for economies seeking to advance their innovation outputs.

This paper consists of five sections. After the introduction, the second part of the paper explores the literature on innovation and competitiveness. The paper continues to explore the link between enabling environment, human capital, markets and innovation ecosystem at the macroeconomic level. Chapter three deals with the global competitiveness report and the methodology that is based on it. Chapter four discusses the analysis and results of multiple regression for the proposed model. In the last fifth chapter, general evaluation and conclusions will be presented together with the implications for Bosnia and Herzegovina.

\section{Literature Review}

"The knowledge-based economy" is a term coined to describe trends in advanced economies towards greater dependence on knowledge, information and high skill levels, and the increasing need for ready access to all of these by the business and public sectors (OECD, 2019). In order to operate on a globalized knowledge-based economy, governments, institutions, companies, and individuals need to continuously improve the way of doing business through technology and innovation (Padilla-Pérez \& Gaudin, 2014). It is almost unanimously accepted that the path to today economic competitiveness is most adequate through innovation and innovativeness of respected countries. Also, competitive enterprises are the key drivers in a country's competitiveness (Ciocanel \& Pavelescu, 2015). Scientific discourses on innovation date back to the time of the Schumpeterian economy in which Schumpeter theorizes that value creation comes from a combination of innovative activities such as introducing new products and services, opening new markets, winning new sources of supply, or creating a monopoly to achieve sustainable competitive advantages (Schumpeter, 1934). He further suggests that organizations that engage in these types of pioneering activities are innovative organizations (Schumpeter, 1934). Recent research on innovation topic is mostly focused on (i) internationalization of products or services (ii) role of technology (iii) antecedents of innovation.

Internationality is itself considered an innovative behavior because it entails a new focus, that is, entry into new markets is typically associated with perceived high insecurity and higher risks (Reid 1981). When it comes to internalization Chang \& Webster (2019) argue that there is a positive relationship between government networks and export likelihood similar to Reid (1981) who states that many factors influence the success or failure of SMEs' entry to international markets suggesting that SME innovativeness, environmental competitiveness, and networks play major roles in SME internationalization success. 
He also adds that internationality is considered an innovative behavior because it entails a new focus, that is, entry into new markets is typically associated with perceived high insecurity and higher risks (Reid, 1981). In order to become competitive, the newly created global companies believe that a crucial ingredient is an innovative culture, as well as knowledge and skills in this unique breed of an international, entrepreneurial firm (Knight \& Cavusgil, 2004).

Technology certainly plays a big role when it comes to all aspects of innovation. Technologically innovative capabilities and the capacity to adopt technologies by individuals, companies and the state are important factors for innovation and competitiveness. Technological innovation capabilities make it possible for firms to respond to changes rapidly and to acquire technological innovation strategies and innovative outputs (Ince et al., 2016). On the other hand, technological innovativeness is often defined as the extent to which a consumer is motivated to be the first to adopt new technology-based goods and services (Bruner \& Kumar, 2007; Thakur, Angriawan, \& Summey, 2016)but have not been the focus of prior scholarly research, are gadget lovers. This article provides insights into this segment, proposes a scale to measure its key characteristics, and reports the results of a group interview and four additional studies that support the validity of the scale $(\mathrm{n} 1=1,655, \mathrm{n} 2=789, \mathrm{n} 3=1,366$, and $\mathrm{n} 4=188$. This technology acceptance or adoption in the context of innovations was also explored recently by Jang \& Lee (2018). Additionally, Martínez-Román \& Romero (2017) in their work stated that one most important factors are capabilities for core/internal innovation and the capabilities for the adoption of technology.

In order to capture most important drivers or antecedents of innovation, many authors explore organizational antecedents of innovation (Popa et al., 2017; Walker, 2014)open innovation (OI or external antecedents (Walker, 2014) that play a certain and important role in achieving the competitive advantage of countries. Popa et al., (2017)open innovation (OI extrapolate this climate for innovation at a firm-level, it is necessary to support knowledge sharing and collaboration across firms' functional areas. Similarly, Walker (2014) analyzed the role of the internal antecedents include organizational size, slack resources, administrative capacity, and organizational learning. Besides this Walker (2014) explored in his paper external antecedents: needs, wealth and urbanization.

From the discussion above, we can see that many factors are consequential for the innovation ecosystem of a country. From environmental factors to human capital and market in general. Enabling environment is very important for doing business and for country prosperity because it contains all supporting factors such as macroeconomic stability, ICT adoption, infrastructure, and institutions. Sivak, Caplanova, \& Hudson (2011) have emphasized in their work the importance of infrastructure for 
innovation and the importance of enabling factors is also proven in other scientific discourse (Jabbouri et al., 2016; Koh \& Koh, 2006). Hence, we propose the hypothesis:

\section{H1. Enabling environment influences the innovation ecosystem.}

Besides environment, we can see how important people skills are when it comes to innovation. The latest World competitiveness report has put more focus on it than ever before. According to this, in this paper, we aim to explore the impact of skills and health systems on the innovation ecosystem of world economies. The main reason is that in modern economy, nations do not rely solely on products and services. The abilities of a nation to develop an excellent educational system and to improve their employment skills through training are vital for competitiveness (Ciocanel \& Pavelescu, 2015). We propose the following hypothesis:

\section{H2. Human capital influences the innovation ecosystem.}

Important element and driver of innovation and sustainability of an economy is financial capacity in the broad sense (e.g. domestic credit to private sector, financing of SMEs, venture capital availability, market capitalization, insurance premium, soundness of banks, non-performing loans, credit gap, banks' regulatory capital ratio, gross domestic product, imports of goods and services). A large strand of literature highlights that firm innovative activity is likely to be more severely affected by financial constraints than fixed capital investment due to the higher complexity, specificity and degree of uncertainty characterizing innovation projects (Mateut, 2018). On the economy level, Hsu, Tian, \& Xu (2014) and Veselovsky, Pogodina, Ilyukhina, Sigunova, \& Kuzovleva (2018) argue that overall country financial development for R\&D investment plays a significant role when it comes to innovation ecosystem. Besides financial part, labor market is also important support factor for innovation environment (Schwab, 2019). Thus, we formulated the following hypothesis:

H3. Markets influences the innovation ecosystem.

In section that follows, we will explain in detail methodology behind GCR.

\section{Methodology}

This study used secondary data on 141 countries from indicators presented in the latest The Global Competitiveness Report for 2019 (Schwab, 2019). The ranking is based on successive aggregations of scores from the indicator level using a specific weighting process (Feldmann et al., 2018). The indicators come from statistical data from 15,000 business executives with the help of 150 Partner Institutes derived from the World Economic Forum's Executive Opinion Survey. 
Innovativeness is a concept that is pervasive at all levels (individual, level company level state) and in this paper will be seen through the prism of the company but will present state and the current situation at the government level.

Recent Global Competitiveness Report offers insights into the economic prospects of 141 economies. Drawing on these results, the report provides leads to unlock economic growth, which remains crucial for improving living standards (Schwab, 2019). This ranking combines 103 indicators grouped into 12 pillars that capture concepts that matter for productivity and long-term prosperity: 1st pillar: Institutions, 2nd pillar: Infrastructure, 3rd pillar: ICT adoption 4th pillar: Macroeconomic stability, 5th pillar: Health, 6th pillar: Skills, 7th pillar: Product market, 8th pillar: Labour market, 9th pillar: Financial system, 10th pillar: Market size, 11th pillar: Business dynamism, 12th pillar: Innovation capability. The indicators for pillars used in this research are presented as follows:

- Institutions consist of security, social capital, checks and balances, $\mathrm{Pu}-$ blic-sector performance, transparency, property rights, corporate governance, future orientation of government

- Infrastructure: transport infrastructure and utility infrastructure.

- ICT adoption consists of mobile-cellular telephone subscriptions, mobile-broadband subscriptions, fixed-broadband internet subscriptions, fiber internet subscriptions, and internet users.

- Macroeconomic stability is measured with: inflation, and debt dynamics.

- Health: healthy life expectancy.

- Skills are related to years of schooling, the extent of staff training, quality of vocational training, the skillset of graduates, digital skills among the active population, ease of finding skilled employees, school life expectancy, critical thinking in teaching and pupil-to-teacher ratio in primary education.

- The product market consists of: distortive effect of taxes and subsidies on competition, competition in services, the prevalence of non-tariff barriers, trade tariffs, the complexity of tariffs, and border clearance efficiency.

- Labor market: redundancy costs, hiring and firing practices, cooperation in labor-employer relations, flexibility of wage determination, active labor market policies, workers' rights, ease of hiring foreign labor, internal labor mobility, reliance on professional management, pay and productivity, ratio of wage and salaried female workers to male workers, labor tax rate. 
- Financial system relates domestic credit to the private sector, financing of SMEs, venture capital availability, market capitalization, insurance premium, soundness of banks, non-performing loans, credit gap and banks' regulatory capital ratio.

- Market size: Gross domestic product, Imports of goods and services.

- Business dynamism: cost of starting a business, time to start a business, insolvency recovery rate, insolvency regulatory framework, attitudes towards entrepreneurial risk, willingness to delegate authority, growth of innovative companies, companies embracing disruptive ideas.

- Innovation capability: diversity of the workforce, state of cluster development, international co-invention, multi-stakeholder collaboration, scientific publications, patent applications, R\&D expenditures, research institutions prominence, buyer sophistication, trademark applications.

But for the purpose of this research pillars are grouped into the following units and will be analyzed as such in this paper: Enabling Environment (1st -4th pillar), Human Capital (5th and 6th pillar), Markets (7th - 10th pillar) and Innovation Ecosystem (11th and 12th pillar) suggested by Schwab (2019). In this paper, empirical analysis will be used in multiple regression method.

\section{Results}

A dependent variable in our study is innovation ecosystems. Specifically, we aim to analyze the impact of enabling environment, human capital, markets on the innovation ecosystem while controlling for GDP of respected countries. Prior to testing the regression model, we performed diagnostic tests for the assumptions of the normality of distribution, multicollinearity and heteroskedasticity. For the normality of distribution, we used the Shapiro-Wilk test that showed that the data are not normally distributed (Table 1). In this regard, we decided not to transform the data, but to employ multiple regression analysis with maximum likelihood (ML) estimation in Lisrel 8.8. software, which is confirmed to be robust under the condition of deviations from normal data distribution (Boomsma \& Hoogland, 2001; Hair et al., 2014, Diamantopoulos \& Siguaw, 2000).

Table 1: Diagnostic tests

\begin{tabular}{|lcccc|}
\hline & Shapiro-Wilk test & VIF & CDF \\
\hline Enabling Environment & 0.976 & 0.013 & 7.389 & 0.800 \\
Human Capital & 0.942 & 0.000 & 4.807 & \\
Markets & 0.977 & 0.018 & & \\
Innovation Ecosystem & 0.955 & 0.000 & 4.064 & \\
\hline
\end{tabular}


Besides, results showed that all variables were within the recommended threshold when it comes to testing multicollinearity (VIF <10) (Hair, Black, Babin \& Anderson, 2010). In order to prove homoscedasticity, we used the Breusch-Pagan test for heteroscedasticity (Breusch \& Pagan, 1979). The Breusch-Pagan test showed that the sample does not contain a violation of homoscedasticity rules $(\mathrm{p}<0.001)$.

We further estimated the proposed multiple regression model and the results are presented in Table 2.

Table 2: Multiple regression analysis

\begin{tabular}{|c|c|c|c|c|c|}
\hline \multicolumn{6}{|c|}{ Coefficientsa } \\
\hline \multirow[t]{2}{*}{ B } & \multicolumn{2}{|c|}{$\begin{array}{l}\text { Unstandardized } \\
\text { Coefficients }\end{array}$} & \multirow[t]{2}{*}{$\begin{array}{c}\text { Standardized } \\
\text { Coefficients }\end{array}$} & \multirow[t]{2}{*}{$\mathbf{t}$} & \multirow[t]{2}{*}{ Sig. } \\
\hline & Std. Error & Beta & & & \\
\hline (Constant) & -11.695 & 2.757 & & -4.292 & .000 \\
\hline Enabling Environment & 0.177 & 0.051 & .194 & 2.274 & .025 \\
\hline Human Capital & 0.021 & 0.083 & .024 & 0.401 & .689 \\
\hline Markets & 0.839 & 2.561 & .615 & 10.158 & .000 \\
\hline GDP (control) & 5.365 & 1.250 & .187 & 8.246 & .000 \\
\hline
\end{tabular}

$$
(F=261.871, p<0.000)
$$

Multiple regression was conducted to predict innovation ecosystems based on environment, human capital and markets. A significant regression equation was found $(\mathrm{F}=261.871, \mathrm{p}<0.000)$. The results highlighted a positive impact of enabling environment and markets on the innovation ecosystem. The coefficient of determination (R2) for this model is 0.885 suggesting that independent variables explain $88.5 \%$ of the variance in the dependent variable. In other words, $88.5 \%$ of the competitiveness of a country's innovation ecosystem is explained by enabling environment, human capital, markets, and GDP. Details in Table 2 suggesting that the F value is 261.871 and is significant at the level of $\mathrm{p}<0.000$ which indicates that the model is suitable for the collected data. We controlled this analysis by GDP of respected countries and the study suggests that there is a significant difference among developed and emerging economies. Furthermore, results suggest that human capital does not have an impact on innovation capability.

\section{Discussion, Conclusions, and Implications}

There is broad agreement among scholars regarding the influence of skills and market in general on the innovation ecosystem of a country. The present study advances the literature on innovation, competitiveness, and sustainability by employing established methodology (Schwab, 2019) in a different setting (applying multiple regression analysis). 
This study seeks to measure the impact of enabling environment, human capital and markets on the innovation ecosystem. For this purpose, multiple regressions were used to analyze the data collected in the Global Competitiveness Report (GCR) 2019 (Schwab, 2019). By bringing the focus on innovation, this research explores the impact of enabling environmental factors that play a crucial role in setting up the innovation ecosystem. With good infrastructure, institutional support, and macroeconomic stable environment countries and companies are more likely to invest in innovation and create an innovation ecosystem. Additional support for this environment is information technologies. ICT is an indispensable factor when it comes to innovation in general. The higher the level of technology acceptance, the greater the opportunity for a more innovative environment.

This study also confirms a previous theory suggesting that the market plays an important role in the innovation ecosystem (Mateut, 2018; Hsu, Tian, \& Xu, 2014). The role of the market can also be one of the limiting or stimulating factors when it comes to the innovation ecosystem. If the labor market or financial market is regulated, there is a greater opportunity for the companies and the countries to thrive and be innovative. Certainly, countries that have a poorly regulated, complex and discouraging market system will not be competitive enough and will be much slower in investing in innovation and creating an innovation culture.

It is evident from the conducted empirical research that skills (e.g. mean years of schooling, the extent of staff training, quality of vocational training, the skillset of graduates, digital skills among the active population) is the most productive area for improvement. Although the role of skills has been emphasized in previous research, other scholars who state that the nation's competitiveness depends on the education system and the skilled personnel (Ciocanel \& Pavelescu, 2015), it has proved to be non-significant in this research. The most logical reason is that people's skills and the health sector are unequally developed in developing and developed economies. Given that the GDP control variable has proven to be significant, future research must examine whether there is a significant difference between regulated and unregulated economies when it comes to the human market.

\section{Implications for $B \& H$}

Generally observed B\&H occupies an unenviable place according to all observed parameters, as in previous years. Poor, at the same time, devastating results on the level of development of innovations, as well as other parameters, were the starting point for the writing of this paper whose main goal was to identify the key determinants of the innovation ecosystem of an economy. As we can see, the significant determinants, after conducting multiple regressions, are those focused on environmental 
factors and market systems. When it comes to the innovation ecosystem, it is evident that B\&H occupies a high 117th place (see table 2) and lag behind the countries in the region (Croatia (73), Slovenia (28), Serbia (59), Macedonia (97), Albania (110)).

Table 3: GCR results

\begin{tabular}{|c|c|c|c|}
\hline Pillars & $\begin{array}{c}\text { BH } \\
\text { Rank }\end{array}$ & Indicators & Implications \\
\hline $\begin{array}{l}\text { Innovation Ecosystem } \\
\text { (Innovation capability } \\
\text { \& Business } \\
\text { Dynamism) }\end{array}$ & 117 & $\begin{array}{l}\text { Diversity of the workforce, state } \\
\text { of cluster development, } \\
\text { international co-invention. } \\
\text { Collaboration, scientific } \\
\text { publications, } \\
\text { patent applications, } \\
\text { R\&D expenditures, } \\
\text { research institutes. } \\
\text { Prominence, buyer } \\
\text { sophistication, } \\
\text { trademark applications }\end{array}$ & $\begin{array}{l}\text { - Investment in R\&D } \\
\text { - } \quad \text { Creation of innovation policies } \\
\text { on country level } \\
\text { - Empowering people skills }\end{array}$ \\
\hline \multicolumn{4}{|c|}{ Significant predictors of the innovation ecosystem } \\
\hline Enabling environment & 86 & $\begin{array}{l}\text { Infrastructure } \\
\text { Institution } \\
\text { ICT adoption } \\
\text { Macroeconomic stability }\end{array}$ & $\begin{array}{l}\text { Need to strengthen their skills and } \\
\text { labor market to minimize the risks } \\
\text { of negative social spillovers }\end{array}$ \\
\hline Human capital & 78 & $\begin{array}{l}\text { Health } \\
\text { Skills }\end{array}$ & $\begin{array}{l}\text { - Talent adaptability also requires a } \\
\text { well-functioning labor market that }\end{array}$ \\
\hline Markets & 99 & $\begin{array}{l}\text { Product market } \\
\text { Labor market } \\
\text { Financial system } \\
\text { Market size }\end{array}$ & $\begin{array}{l}\text { protects workers rather than jobs. } \\
\text { Strengthening financial system } \\
\text { regulations }\end{array}$ \\
\hline
\end{tabular}

This situation provides the opportunity to improve the innovation ecosystem through the creation of innovation policies and additional investment in R\&D, empowering people skills that are currently insufficient. Additional, creating of possibilities for funding, $R \& D$, possibilities for companies to allocate in their budgets or to be exempt from some taxes in order to stimulate $R \& D$ investment are some examples where $\mathrm{B} \& \mathrm{H}$ can benefit and improve innovation culture. In this way, innovation will become the result.

Recommendations for improvement based on WCR and results from our research suggest focusing on improvement in the field of skills, labor market, financial system, and market size trough at least activities and that follows:

1. It is of huge importance for productivity to make human capital investments. This focus on people, skill is one of the most critical factors of productivity.

2. The key components underpinning flexicurity - flexible contractual arrangement, life-long learning, active labour-market policies, worker rights' protection-are captured in the GCI through several indicators within the Labour market and the Skills pillars. 
3. Focusing on financial development and innovation capability would help the region to achieve a higher competitiveness performance and advance the process towards structural change.

Finally, to answer the question from the title of the paper, we can say that innovation is definitely the answer for the long-term sustainability and competitiveness of a country, and this is one of the greatest opportunities for the economic growth of $\mathrm{B} \& \mathrm{H}$.

\section{BIBLIOGRAPHY}

1. (OECD), O. for E. C. and D. (2019). Organisation for Economic Co-operation and Development (OECD). In Oslo Manual GUIDELINE GUIDELINES FOR COLLECTING AND INTERPRETING INNOVATION DATA 3rd edition. OECD Publishing. https://doi.org/10.4337/9781786438935.00024

2. Boomsma, A., \& Hoogland, J. J. (2001) 'The Robustness of LISREL Modeling Revisited', Structural equation modeling Present and future, pp. 139-168.

3. Breusch, T. S., \& Pagan, A. R. (1979). A Simple Test for Heteroscedasticity and Random Coefficient Variation. Econometrica, 47(5).

4. Bruner, G. C., \& Kumar, A. (2007). Gadget lovers. Journal of the Academy of Marketing Science, 35(3), 329-339. https://doi.org/10.1007/s11747-007-0051-3

5. Chang, F. Y. M., \& Webster, C. M. (2019). Influence of Innovativeness, Environmental Competitiveness and Government, Industry and Professional Networks on SME Export Likelihood. Journal of Small Business Management, 57(4), 1304-1327. https://doi.org/10.1111/jsbm. 12446

6. Ciocanel, A. B., \& Pavelescu, F. M. (2015). Innovation and Competitiveness in European Context. Procedia Economics and Finance, 32(15), 728-737. https:// doi.org/10.1016/s2212-5671(15)01455-0

7. Diamantopoulos, A., \& Siguaw, J. (2000). Introducing LISREL: A Guide for the Uninitiated. SAGE Publications Ltd; 1 edition (September 22, 2000).

8. Feldmann, P., Jacomossi, R., Barrichello, A., \& Morano, R. (2018). The relationship between Innovation and Global Competitiveness: The mediating role of Management Practices evaluated by Structural Equation Modeling. Review Of Business Management, 21(2), 195-212. https://doi.org/10.7819/rbgn. v21i 2.3970

9. Fonseca, L. M., \& Lima, V. M. (2015). Countries three wise men: Sustainability innovation, and competitiveness. Journal of Industrial Engineering and Management, 8(4), 1288-1302. https://doi.org/10.3926/jiem.1525 
10. Hair, J.F., Black, W.C., Babin, B.J., Anderson, R. E. (2010). Multivariate Data Analysis (7th Edition). Prentice Hall; 7 edition.

11. Hsu, P. H., Tian, X., \& Xu, Y. (2014). Financial development and innovation: Cross-country evidence. Journal of Financial Economics, 112(1), 116-135. https://doi.org/10.1016/j.jfineco.2013.12.002

12. Ince, H., Imamoglu, S. Z., \& Turkcan, H. (2016). The Effect of Technological Innovation Capabilities and Absorptive Capacity on Firm Innovativeness: A Conceptual Framework. Procedia - Social and Behavioral Sciences, 235(October), 764-770. https://doi.org/10.1016/j.sbspro.2016.11.078

13. Jabbouri, N. I., Siron, R., Zahari, I., \& Khalid, M. (2016). Impact of Information Technology Infrastructure on Innovation Performance: An Empirical Study on Private Universities In Iraq. Procedia Economics and Finance, 39(November 2015), 861-869. https://doi.org/10.1016/s2212-5671(16)30250-7

14. Jang, S. H., \& Lee, C. W. (2018). The impact of location-based service factors on usage intentions for technology acceptance: The moderating effect of innovativeness. Sustainability (Switzerland), 10(6), 1-18. https://doi.org/10.3390/ su10061876

15. Knight, G. a, \& Cavusgil, S. T. (2004). Innovation, organizational capabilities, and the born-global firm. Journal of International Business Studies, 35(2), 124141. https://doi.org/10.1057/palgrave.jibs. 8400071

16. Koh, W. T. H., \& Koh, W. T. H. (2006). Singapore 's Transition to Innovation-based Economic Growth : Infrastructure, Institutions and Government's Role Singapore 's transition to innovation-based economic growth : infrastructure, institutions and government' s role. R\&D Management, 36(2), 143-160.

17. Kowal, J., \& Paliwoda-Pękosz, G. (2017). ICT for Global Competitiveness and Economic Growth in Emerging Economies: Economic, Cultural, and Social Innovations for Human Capital in Transition Economies. Information Systems Management, 34(4), 304-307. https://doi.org/10.1080/10580530.2017.1366215

18. Martínez-Román, J. A., \& Romero, I. (2017). Determinants of innovativeness in SMEs: disentangling core innovation and technology adoption capabilities. Review of Managerial Science, 11(3), 543-569. https://doi.org/10.1007/s11846016-0196-x

19. Mateut, S. (2018). Subsidies, financial constraints and firm innovative activities in emerging economies. In Small Business Economics (Vol. 50, Issue 1). Small Business Economics. https://doi.org/10.1007/s11187-017-9877-3

20. Padilla-Pérez, R., \& Gaudin, Y. (2014). Science, technology and innovation policies in small and developing economies: The case of Central America. Resear- 
ch Policy, 43(4), 749-759. https://doi.org/10.1016/j.respol.2013.10.011

21. Popa, S., Soto-Acosta, P., \& Martinez-Conesa, I. (2017). Antecedents, moderators, and outcomes of innovation climate and open innovation: An empirical study in SMEs. Technological Forecasting and Social Change, 118, 134-142. https://doi.org/10.1016/j.techfore.2017.02.014

22. Porter, M. (1990). The Competitive Advantage of Nations. Harward Business Review, 17(1), 213-215. https://doi.org/10.1177/014920639101700113

23. Reid, S. D. (1981). The Decision-Maker and Export Entry and Expansion. Journal of International Business Studies, 12(2), 101-112. https://doi.org/10.1057/ palgrave.jibs. 8490581

24. Schumpeter, J. A. (1934). The Theory of Economic Development. An Inquiry into Profits, Capital, Credit, Interest, and the Business Cycle. Translated from the German by Redvers Opie, 7th ed. Vol. XLVI. Harvard Business School Press.

25. Schwab, K. (2019). The Global competitiveness report 2019. In Choice Reviews Online (Vol. 44, Issue 10). World Economic Forum. https://doi.org/10.5860/ choice.44-5759

26. Şener, S., \& Sarıdoğan, E. (2011). The Effects Of Science-TechnologyInnovation On Competitiveness And Economic Growth. Procedia - Social and Behavioral Sciences, 24, 815-828. https://doi.org/10.1016/j.sbspro.2011.09.127

27. Sivak, R., Caplanova, A., \& Hudson, J. (2011). The impact of governance and infrastructure on innovation. Post-Communist Economies, 23(2), 203-217. https://doi.org/10.1080/14631377.2011.570050

28. Veselovsky, M. Y., Pogodina, T. V., Ilyukhina, R. V., Sigunova, T. A., \& Kuzovleva, N. F. (2018). Financial and economic mechanisms of promoting innovative activity in the context of the digital economy formation. Entrepreneurship and Sustainability Issues, 5(3), 672-681. https://doi.org/10.9770/jesi.2018.5.3(19)

29. Walker, R. M. (2014). Internal and External Antecedents of Process Innovation: A review and extension. Public Management Review, 16(1), 21-44. https://doi. org/10.1080/14719037.2013.771698 
Zlatko Lagumdžija, PhD

Amra Kapo, PhD

Lejla Turulja, $\mathrm{PhD}$

\section{OD KONKURENTNOSTI DO ODRŽIVOSTI: DA LI JE INOVATIVNOST ODGOVOR?}

\section{SAŽETAK}

Živimo u globalnom društvu koje se brzo mijenja, u kojem niko ne može predvidjeti ishod ekonomske, socijalne i političke strukture svijeta. Promjene u nauci, tehnologiji i ekonomiji posebno su uočljive i usko povezane s ljudskim životom. Te promjene stvaraju nove mogućnosti, ali i izazove u novim područjima svakodnevnog djelovanja u cilju postizanja održivog razvoja. Da bi se države međusobno nadmetale, moraju biti kreativne i inovativne na svim poljima kako bi se mogle nositi s domaćim, nacionalnim i globalnim pitanjima. Trenutna konkurentnost temelji se na mogućnostima zemlje i njihovih kompanija da budu i ostanu inovativni. To je glavni razlog zašto mnoge vlade stavljaju inovativnost u središte svojih strategija rasta kako bi potaknule privredni napredak i globalnu konkurentnost u cjelini. Prepoznavanje $i$ potreba za prepoznavanjem inovacije kao pokretača promjena očigledno je i na razini komapnije. Ova studija će koristiti sekundarne podatke prikupljene ove godine sa Svjetskog ekonomskog foruma kako bi se identificirali kritični izazovi i mogućnosti za konkurentnost BiH. Također, rezultati ovog istraživanja identificirali su uticaj inovacijskog ekosistema na okoliš i tržišta. Praktični doprinos se odnosi na konkretne implikacije i preporuke koje se mogu iskoristiti za poboljšanje inovativnosti Bosne i Hercegovine. 